\title{
ADSORPTION OF COPPER IN SOIL AND ITS DEPENDENCE ON PHYSICAL AND CHEMICAL PROPERTIES
}

\author{
Vítězslav Vlček ${ }^{1}$, Miroslav Pohanka ${ }^{2,3}$ \\ ${ }^{1}$ Faculty of Agri Science, Mendel University in Brno, Zemědělská 1, 613 00, Brno, Czech Republic \\ ${ }^{2}$ Faculty of Military Health Sciences, University of Defense, Třebešská 1575, 50001 Hradec Králové, Czech Republic \\ ${ }^{3}$ Faculty of Forestry and wood technology, Mendel University in Brno, Zemědělská 1, 613 00, Brno, Czech Republic
}

\begin{abstract}
VLČEK VÍTĚZSLAV, POHANKA MIROSLAV. 2018. Adsorption Of Copper in Soil and its Dependence on Physical and Chemical Properties. Acta Universitatis Agriculturae et Silviculturae Mendelianae Brunensis, 66(1): 219-224.

Soil samples $(n=11)$ were collected in the chernozem areas of the Czech Republic (the Central Europe) from the topsoil and used as representative samples. All sampling areas have been used for agricultural purposes (arable soil) and they were selected as typical representatives of agricultural soil. These samples represented the soil with same genesis (to reduction differencies between soil types) but with different soil properties (physical and chemical). Complete chemical and physical analyses were made for confirmation of copper adsorption on solid phase: we analysed the particle size distribution, content of oxidizable carbon (Cox), the cation exchange capacity (CEC), supply of exchange calcium, magnesium, sodium, phosphorus and potassium, soil reaction and the total supply of Fe, Al, Mn, Ca, Mg, K, P and N. The strongest simple correlation between analysed soil properties and copper concentration had content of available magnesium $(\mathrm{r}=0.44)$ and available phosphorus $(\mathrm{r}=-0.51)$. In the case of multiple correlations (i. e. collective influence of multiple soil properties) had the strongest influence combination of clay, soil reaction, total content of phosphorus, available magnesium and available phosphorus. The main influence of phosphorus and magnesium is evident. We suppose that copper and phosphorus enter into specific complex. Influence of these five soil properties can explain $92.7 \%(r=0.927)$ changes in the content of copper changes in the experiment.
\end{abstract}

Keywords: copper; toxicity; copper adsorption; chernozem soil; heavy metal

\section{INTRODUCTION}

Copper is currently widely used metal in many technical fields (transport, manufacturing, electricity transmission), but also in agriculture (fungicides, herbicides). Wilful use of copper in agricultural is in the inorganic form (Copper (II) sulfate; copper oxychloride, copper (II) hydroxide) or in the organic form (copper salt with naphthenic acid; 8-hydroxyquinoline copper (II) etc.). Despite the fact that copper is necessary microbiogenic element, its toxicity is not negligible. Mammals are relatively resistant to acute toxic effects of copper. This is due to the fact that the organism rapidly displaces free copper to copper-binding proteins, such as transport ceruloplasmin and in overdose on albumin (Pal et al., 2014). The presence of copper in the body is not without risks and it is expected that poorly efficient copper-binding proteins or excessive uptake of copper may contribute to the development of the diseases, for which no data has clearly demonstrated etiology. In the literature there were discussed cardiovascular illnesses (Pohanka, 2013), Parkinson (Montes et al., 2014) and Alzheimer (Pohanka, 2013) disease etc. But effect of copper is wider for example strong non-competitive inhibition of acetylcholinesterase (Pohanka, 2014) and affects activity of kinase which controls cell cycle (Brady et al., 2014). It is thought that copper can initiate deterioration of oncological diseases prognosis via the kinases.

Understanding of copper sorption in the soil is relatively important for reduction of the food chain 
contamination. Average content in the Earth's crust is relatively low content (it's reported at $70 \mathrm{ppm}$ for klark). Natural contents in the soils are between 2 and 250 ppm, on average 30 ppm (Adriano, 2013); Benes (1993) shows the average content for surface horizon in Central Europe 22 ppm. In soil, copper could be found: in the soil solution, adsorbed on exchange sites in the soil, in the oxides, in the crystal lattice of primary and secondary minerals (Selbig et al., 2013) and in soil organic matter and living organisms (Adriano, 2013). The concentration of copper ions in the soil solution is relatively low, the major part is bound on soil colloids: clay minerals (Al-Qunaibit et al., 2004), soil organic matter, aluminium and/or iron oxides (Cavallaro and McBride, 1984; Boujelben et al., 2009), natural zeolites (Erdem et al., 2004) etc. Sorption/desorption of heavy metals in soil therefore depends on the type of soil. Copper has a very high affinity to organic material and the bond between the organic material and copper is much stronger than with other heavy metals (Adriano, 2013). Therefore, in this type of medium it may lead to accumulation. Bonding mainly happens in phenolic and carboxyl functional groups (Kabata and Penditas, 1984). The study of Meima et al. (1999) showed the effects of dissolved organic carbon (DOC) on copper leaching from the ash after combustion of municipal solid waste. Compounds had mainly high molecular weight (> $10 \mathrm{kDa})$. In the absence of DOC copper mobility decreased by 2 to 3 orders of magnitude. From this perspective, carboxyl groups of humic acids play a dominant role (Alloway, 1995). We expect the high affinity of organic matter to copper is due to the it's high sorption capacity, as well its ability to chelation (Adriano, 2013). Copper presented in the soil solution is most often bonded to DOC (Frost et al., 2015). Copper is also specifically adsorbed on oxides of Fe, Al, Mn (Diagboya et al., 2015). According to Adriano (2013) the affinity of copper additionally decreases in the chain $\mathrm{Mn}$ oxides $>$ organic matter $>\mathrm{Fe}$ oxides $>$ clay minerals, however some other studies have attributed a main influence to organic colloids or clay minerals (Frost et al., 2015). Decrease of soil reaction causes desorption of previously adsorbed copper in the soil. Quantity of desorbed copper depends on soil kind and decreasing $\mathrm{pH}$ (Ali et al., 2016). On the adsorption capacity, there is also significant influence of particle size: metals were highly concentrated on the coarse (sand) and fine fraction (clay). Low concentration in the silt fraction has been linked to the presence of light minerals such as silica in a higher concentration than in other fraction (Huang and Jing, 1990). From this perspective adsorption is one of the most important processes that affect the bioavailability of metals in the soil. This is because it affects the concentration of metal ions and complexes in soil solution. In this work, we have focused our research on the determination of copper affinity on soil samples and the determination of factors having impact on the affinity. The soils chosen for the experiment were collected from typical areas with intensive agriculture and the findings can be easily generalized.

\section{MATERIALS AND METHODS}

\section{Soil samples analysis}

Selected soils are concentrated in the South Moravia region and their properties can be generalized as typical agricultural soils with higher content and quality of humus. The objects of study included the upper humus horizons $(\mathrm{N}=11)$ of a soil type chernozem. It represents the soil with similar soil genesis and with similar accumulation of soil organic matter in mollic horizon, but on different soil-forming substrates (sand with carbonates, loess, marl) and with different soil properties see Tab. I. Soil samples were prepared for chemical and physical analysis according ISO 11464. The particle size analysis was performed by the pipette method after the pyrophosphate pre-treatment of the samples. We defined (including

I: Basic physical and chemical description of localities

\begin{tabular}{lccccccc}
\hline \multicolumn{1}{c}{ Locality } & $\begin{array}{c}\text { Clay } \\
(\%)\end{array}$ & $\begin{array}{c}\text { Silt } \\
(\%)\end{array}$ & Sand (\%) & $\begin{array}{c}\text { Cox } \\
(\%)\end{array}$ & pH/H $\mathbf{O}$ & pH/KCl & $\begin{array}{c}\text { CEC } \\
\mathbf{m M} / \mathbf{k g}\end{array}$ \\
\hline Borsice u Blatnice & 23.1 & 64.2 & 12.7 & 1.32 & 7.9 & 7.2 & 405 \\
Branisovice & 21.0 & 59.1 & 19.9 & 2.03 & 7.4 & 6.6 & 275 \\
Brezi & 0.5 & 16.9 & 82.6 & 0.86 & 7.9 & 7.6 & 106 \\
Hrusky 1 & 8.7 & 69.3 & 22.0 & 2.53 & 7.5 & 7.1 & 279 \\
Hrusky 2 & 9.0 & 69.9 & 21.1 & 2.11 & 7.7 & 7.2 & 304 \\
Dubany & 7.7 & 75.0 & 17.3 & 3.57 & 7.2 & 6.7 & 358 \\
Trebetice & 3.7 & 77.0 & 19.3 & 2.07 & 7.8 & 7.2 & 318 \\
Damnice & 6.1 & 73.1 & 20.8 & 2.03 & 7.9 & 7.3 & 282 \\
Vazany 1 & 2.2 & 82.0 & 15.8 & 3.03 & 6.6 & 5.9 & 292 \\
Vazany 2 & 10.9 & 78.3 & 10.8 & 2.98 & 7.0 & 6.1 & 316 \\
Prace & 6.2 & 75.1 & 18.7 & 1.80 & 7.7 & 7.3 & 243 \\
\hline
\end{tabular}


fraction clay-silt-sand) texture fraction $0.1-2 \mathrm{~mm}$, 0.05-0.1 mm, 0.01-0.05 mm, $\quad 0.002-0.01 \mathrm{~mm}$ The content of Cox/humus was determined by the Walkley-Black method; with Novak-Pelisek modification (C oxidised by $0.167 \mathrm{M} \mathrm{K}_{2} \mathrm{Cr}_{2} \mathrm{O}_{7}$ with addition of $\mathrm{H}_{2} \mathrm{SO}_{4}$, retitration with $0.5 \mathrm{M}$ Ammonium iron (II) sulfate); the cation exchange capacity (CEC) and content of exchange calcium, magnesium, sodium, phosphorus and potassium were determined by the Mehlich III method; the $\mathrm{pH}$ ( $\mathrm{KCl}$ and $\mathrm{H}_{2} \mathrm{O}$ ) was determined by potentiometry. The total content of iron, aluminium, manganese, calcium, potassium, magnesium and phosphorus were determined by FAAS (Flame atomic absorbtion spectroscopy) method; total nitrogen (Nt) was determined by the Kjeldal method. All soil analysis are shown in Pospisilova et al. (2016).

\section{Copper assay}

In a total $250 \mathrm{mg}$ of soil sample was get into $1 \mathrm{ml}$ of $15.7 \mathrm{mM} / \mathrm{lCuCl}_{2}$ and let to incubate on horizontal shaker adjusted at 800 RPM for $2 \mathrm{~h}$. After that, the mixtures were centrifuged at $10,000 \times \mathrm{g}$ for $10 \mathrm{~min}$ and supernatant was collected. Bismuthiol, a compound with proper chemical name 1,3,4-thiadiazole-2,5-dithiol, was used for copper assay. The bismuthiol was purchased from Sigma-Aldrich (St. Louis, Missouri, USA) as a substance in analytical purity ( $\geq 99 \%)$. Assay based on the bismuthiol was derived from paper of Ahmed et al. (2002).

The bismuthiol was dissolved in deionized water (prepared through Aqua Osmotic system; Aquaosmotic company, Tisnov, Czech Republic) up to concentration $4.42 \mathrm{mM} / \mathrm{l}$. Following reagents were added in one tube: $60 \mu \mathrm{l}$ of sample prepared by the aforementioned way, $7.1 \mathrm{ml}$ of $4.42 \mathrm{mM} / \mathrm{l}$ bismuthiol, $1.4 \mathrm{ml}$ of $0.01 \mathrm{mM} / \mathrm{l} \mathrm{H}_{2} \mathrm{SO}_{4}$, and $1.4 \mathrm{ml}$ of deionized water. The mixture was let to incubate for $30 \mathrm{~min}$ and absorbance at $390 \mathrm{~nm}$ was measured.

\section{Statistical analysis}

Differences between calculated and measured copper content (in multiple correlation) were tested with an analysis of variance (ANOVA) at probability level $\alpha=0.05$. The statistical analysis were done using program Excel 2007 and STATISTICA ver. 11 (@StatSoft Inc.; Tulsa USA).

\section{RESULTS AND DISCUSSION}

\section{Variation range of particle size analysis:}

Content of sand particles were from 10.7 to $82.7 \%$; content of silt particles were from 16.9 to $82.0 \%$ and content of clay particles were from 0.5 to $23.1 \%$. Mainly it was silt loam. Average content of the particles $(0.1-2.0 \mathrm{~mm})$ was $14.3 \pm 6.7 \%$; particles (0.05-0.1 mm) was $9.4 \pm 1.1 \%$; $(0.01-0.05 \mathrm{~mm})$ was $39.1 \pm 3.6 \%$; $(0.01-0.002 \mathrm{~mm})$ was $28.1 \pm 2.1 \%$ and particles $(<0.002 \mathrm{~mm})$ was $9.0 \pm 2.2 \%$. Correlation between texture and copper is weak. The strongest, but negative correlation (-0.21) was within fraction $0.01-0.05 \mathrm{~mm}$ (part of silt particles) and the strongest positive correlation was with clay fraction (0.14) see Tab. II. Negative correlation with silt corresponded with results by Huang and Jing (1990), which did show connection between low concentration of copper in silt fraction and high concentration of light minerals (e.g. silica) in silt. We can agree with results, that the finest particles (clay) are the most responsible for adsorption of copper (Al-Qunaibit et al., 2004).

\section{Variation range of soil reaction:}

Active soil reaction $\left(\mathrm{pH} / \mathrm{H}_{2} \mathrm{O}\right)$ is from 6.6 to 7.9 (from weakly acidic to weakly alkaline; in average $7.51 \pm 0.12)$, and potencial soil reaction $(\mathrm{pH} / \mathrm{KCl})$ is from 5.9 to 7.6 (from weakly acidic to weakly alkaline; in average $6.92 \pm 0.16$ ). Individual correlation with copper is very weak. Soil reaction affects the copper adsorption by other soil properties. We supposed that the poor individual correlation is caused by different uptake in the course of increasing or decreasing soil reaction. It is not a simple correlation. The active soil reaction (in the soil solution) affects the copper uptake at the earliest.

\section{Variation range of soil organic mater content and total nitrogen:}

Variation range of Cox is from $0.86 \%$ (low content) to $3.57 \%$ (very high content). Variation range of total nitrogen is from $0.06 \%$ to $0.30 \%$. Variation range of C:N ratio is from 10.2 to 14.5 . Average content of Cox was $2.21 \pm 0.24 \%$, nitrogen $0.18 \pm 0.02 \%$ and C:N ratio $12.3 \pm 0.4$. All correlations are negative and relative weak: for $\operatorname{Cox} r=-0.14$, and $r=-0.21$ for total nitrogen. But correlation between C:N ratio and copper content is positive and high $(\mathrm{r}=0.35)$. The high correlation between Cox and copper was not confirmed, but if we did fractionation of organic matter, we would find some correlation (for example in fraction dissolved organic matter or in humic acids).

\section{Variation range of $\mathrm{CEC}$ :}

Variation range of cation exchange capacity is from $106 \mathrm{mM} / \mathrm{kg}$ (low CEC), to $406 \mathrm{mM} / \mathrm{kg}$ (very high CEC). Average CEC was $289 \pm 22.6 \mathrm{mM} / \mathrm{kg}$. Variation range of CEC saturation is relatively limited: from 99.1 to $99.8 \%$. Correlations with copper are high: $\mathrm{r}=-0.30$ pro CEC and $\mathrm{r}=-0.20$ for CEC saturation.

\section{Variation range of elements:}

A lot of papers (Alloway and Jacson, 1991; Gongmin et al., 1991; Boujelben et al., 2009) showed relation between copper adsorption and total content of some elements (Fe, Al, Mn). The highest level of negative correlation was with content of available phosphorus $(\mathrm{r}=-0.51)$, the highest positive correlation was with content of available magnesium $(r=0.44)$. 
The key position of phosphorus and magnesium is evident from the showed results. We suppose that copper and phosphorus enter into complex, where does not participate magnesium (positive and negative correlation). Example of phosphorus and copper compound could be $\mathrm{Cu}_{3}\left(\mathrm{PO}_{4}\right)_{2}$ i.e. copper phosphate and $\mathrm{Mg}_{3}\left(\mathrm{PO}_{4}\right)_{2}$ magnesium phosphate (in the case of phosphorus and magnesium compound). In this compound, magnesium would block phosphorus which could react with copper. Solubility equilibrium $\left(\mathrm{K}_{\mathrm{sp}}\right)$ corresponds for example with this assumption: $\mathrm{K}_{\mathrm{s}}\left(\mathrm{Cu}_{3}\left(\mathrm{PO}_{4}\right)_{2}\right)$ is $1.4 \times 10^{-37} \mathrm{~mol} / \mathrm{l}$ and $\mathrm{K}_{\mathrm{s}}\left(\mathrm{Mg}_{3}\left(\mathrm{PO}_{4}\right)_{2}\right)$ is $1 \times 10^{-25} \mathrm{~mol} / \mathrm{l}$. The higher the solubility constant means that the compound is better soluble.

\section{Multiple correlation:}

In the case of multiple correlations the strongest correlation were founded with clay content, soil reaction with water, content of available magnesium and phosphorus and total content of phosphorus. We can explain by these properties approximately $92.7 \%$ of changes in the copper content in the samples (see Fig. 1). Equation (1) of multiple correlations is:

Copper content $=1.944-(8.83 \mathrm{E}-3 . \mathrm{C})-$

$-(0.179 . S R)+(2.61 E-4 . A M)-(9.24 E-4 . A P)-$

$-(7.11 \mathrm{E}-6 . \mathrm{TP})$

where

copper content in the $\mathrm{CuCl}_{2}$ form $(\mu \mathrm{g} / \mathrm{l})$;

C.......................clay content in \%;

SR ...................soil reaction in $\mathrm{H}_{2} \mathrm{O}$;

AM ..................available magnesium in ppm;

AP .....................available phosphorus in ppm;

TP ..................total phosphorus in ppm.

Analysis of variance (ANOVA test at $\alpha=0.05$ ) between calculated and measured content of copper is defined in Tab. III.

$\mathrm{F} \leq \mathrm{F}_{\text {critical }}$ so variances between measured and calculated groups are not statisticaly different at $\alpha=0.05$.

Within the simple correlation, the largest positive correlation (between content of copper in the form of $\mathrm{CuCl}_{2}$ and observed soil properties) was found

II: Content of copper and its correlation with all other soil properties $(N=11)$

\begin{tabular}{|c|c|c|}
\hline Soil properties & & $\begin{array}{l}\text { Simple correlation with copper } \\
\text { (R) }\end{array}$ \\
\hline \multirow{5}{*}{ Particle size analysis } & $0.1-2 \mathrm{~mm}$ & 0.05 \\
\hline & $0.05-0.1 \mathrm{~mm}$ & -0.07 \\
\hline & $0.01-0.05 \mathrm{~mm}$ & -0.21 \\
\hline & $0.002-0.01 \mathrm{~mm}$ & -0.08 \\
\hline & $\leq 0.002 \mathrm{~mm}$ & 0.14 \\
\hline \multirow{2}{*}{ Soil reaction } & $\mathrm{pH} / \mathrm{H}_{2} \mathrm{O}$ & 0.03 \\
\hline & $\mathrm{pH} / \mathrm{KCl}$ & -0.10 \\
\hline \multirow{4}{*}{ Elements on CEC } & $\mathrm{Ca}[\mathrm{mM} / \mathrm{kg}]$ & -0.36 \\
\hline & $\mathrm{Mg}[\mathrm{mM} / \mathrm{kg}]$ & 0.43 \\
\hline & $\mathrm{Na}[\mathrm{mM} / \mathrm{kg}]$ & -0.41 \\
\hline & $\mathrm{K}[\mathrm{mM} / \mathrm{kg}]$ & -0.33 \\
\hline \multirow{3}{*}{ Cation exchange capacity } & $\mathrm{S}[\mathrm{mM} / \mathrm{kg}]$ & -0.30 \\
\hline & $\mathrm{T}[\mathrm{mM} / \mathrm{kg}]$ & -0.30 \\
\hline & V (\%) & -0.20 \\
\hline Cox/humus & $(\%)$ & -0.14 \\
\hline Nt & $(\%)$ & -0.21 \\
\hline Ratio C/N & & 0.35 \\
\hline \multirow{4}{*}{ available nutrients } & $\mathrm{Ca}[\mathrm{ppm}]$ & -0.10 \\
\hline & $\mathrm{K}[\mathrm{ppm}]$ & -0.33 \\
\hline & $\mathrm{Mg}$ [ppm] & 0.44 \\
\hline & $\mathrm{P}[\mathrm{ppm}]$ & -0.51 \\
\hline \multirow{7}{*}{ total elements } & Fe [ppm] & -0.38 \\
\hline & $\mathrm{Al}[\mathrm{ppm}]$ & -0.31 \\
\hline & Mn [ppm] & -0.26 \\
\hline & $\mathrm{Ca}[\mathrm{ppm}]$ & 0.16 \\
\hline & $\mathrm{Mg}$ [ppm] & 0.19 \\
\hline & $\mathrm{K}[\mathrm{ppm}]$ & -0.26 \\
\hline & $\mathrm{P}$ [ppm] & -0.49 \\
\hline
\end{tabular}


III: ANOVA test at $\alpha=0.05(N=11)$ between calculated (Eq. 1) and measured content of copper

\begin{tabular}{lccc}
\hline \multicolumn{1}{c}{ Source of variability } & $\begin{array}{c}\text { Between groups (influence } \\
\text { factor) }\end{array}$ & $\begin{array}{c}\text { Within groups } \\
\text { (other fluctuation) }\end{array}$ & Total \\
\hline Sum of squares & $3.8210^{-05}$ & $2.0910^{-01}$ & $2.0910^{-01}$ \\
Mean Square & $3.810^{-05}$ & $1.010^{-02}$ & \\
F-ratio & 0.004 & & \\
Signific.level P & 0.952 & & \\
F critical & 4.351 & & \\
\hline
\end{tabular}

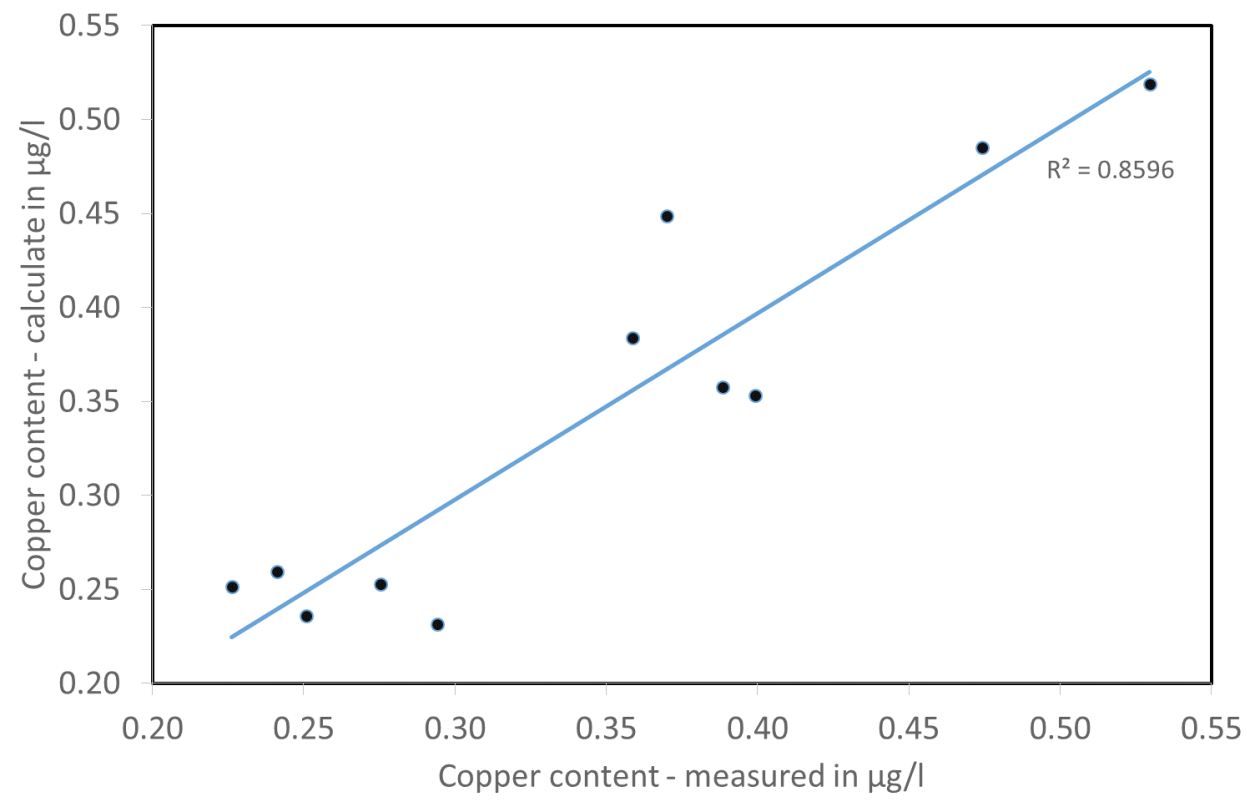

1: Correlation between measured and calculated content of copper in $\mu \mathrm{g} / \mathrm{l}$ according (Eq.1).

in available magnesium content $(r=0.44)$ and within a negative correlation with the available phosphorus content $(\mathrm{r}=-0.51)$. Within of multiple correlations were the greatest correlation founded with clay content, soil reaction, content of available magnesium and phosphorus and total content of phosphorus. We can explain that by showing properties approx. $92.7 \%\left(r^{2}=0.86\right)$ changes of the copper content in the solution. The key position of available phosphorus and magnesium is evident. We suppose that copper and phosphorus enter into complex, where magnesium does not participate but it would block phosphorus which could react with copper (positive and negative correlation).

\section{CONCLUSION}

In this paper, we identified key parameters of soils responsible for their ability to bind free copper. Phosphorus and magnesium content appears to be crucial factor but clay is also a factor. While magnesium containing soils are more suitable for retence of copper, phosphorus content causes lower affinity toward the soil. The fact should be taken into consideration when agricultural preparations like fungicides are applied. The findings can be generalized to other similar types of soils.

\section{Acknowledgement}

A long-term organization development plan 1011 (Faculty of Military Health Sciences, University of Defence, Czech Republic) and the Grant No. QK1810233 "Quantification of the impact farming management on soil erosion, soil quality and yields of crops with proposals of the environmentally friendly cultivation technologies" (funded by the National Agricultural Research) are gratefully acknowledged. 


\section{REFERENCES}

ADRIANO, D. C. (Ed.) 2013. Trace Elements in Terrestrial Environments: Biogeochemistry, Bioavailability, and Risks of Metals. New York: Springer-Verlag.

AHMED, M. J., JAHAN, I. and BANOO, S. 2002. A simple spectrophotometric method for the determination of copper in industrial, environmental, biological and soil samples using 2,5-dimercapto-1,3,4-thiadiazole. Anal Sci, 18(7): 805-810.

ALI, R. M., HAMAD, H. A., HUSSEIN, M. M. et al. 2016. Potential of using green adsorbent of heavy metal removal from aqueous solutions: Adsorption kinetics, isotherm, thermodynamic, mechanism and economic analysis. Ecol engine, 91: 317-332.

ALLOWAY, B. J. (Ed.) 1995. Heavy metals in soils. Glasgow.

ALLOWAY, B. J. and JACKSON, A. P. 1991. The behavior of heavy-metals in sewage sludge-amended soils. Sci. Total Environ. 100: 151-176.

AL-QUNAIBIT, M. H., MEKHEMER, W. K. and ZAGHLOUL, A. A. 2004. The adsorption of Cu(II) ions on bentonite-a kinetic study. J. Colloid Interface Sci, 283(2): 316-321.

BENES, S. 1993. Content and balance of elements in the spheres of environment. I. part. Praha: The Ministry of Environment of the Czech Republic.

BOUJELBEN, N., BOUZID, J. and ELOUEAR, Z. 2009. Adsorption of nickel and copper onto natural iron oxide-coated sand from aqueous solutions: study in single and binary systems. J Hazard Mater, 163(1): 376-382.

BRADY, D. C., CROWE, M. S., TURSKI, M. L. et al., 2014. Copper is required for oncogenic BRAF signalling and tumorigenesis. Nature, 509(7501): 492.

CAVALLARO, N. and MCBRIDE, M. B. 1984. Zinc and copper sorption and fixation by an acid soil clay: effect of selective dissolutions. Soil Sci. Soc. Am. J., 48(5): 1050-1054.

DIAGBOYA, P. N., OLU-OWOLABI, B. I. and ADEBOWALE, K. O. 2015. Effects of time, soil organic matter, and iron oxides on the relatice retention and redistribution of lead, cadmium and copper in soils. Environ. Sci.Pollut. Res., 22(13): 10331-10339.

ERDEM, E., KARAPINAR, N. and DONAT, R. 2004. The removal of heavy metal cations by natural zeolites. J. Colloid Interface Sci., 280(2): 309-314.

FROST, P. C., SONG, K., BUTTLE, J. M., et al. 2015. Urban biogeochemistry of trace elements: What can the sediments of stormwater ponds tell us? Urban ecosystems, 18(3): 763-775.

FU, G. M., ALLEN, H. E. and COWAN, C. E. 1991. Adsorption of cadmium and copper by manganese oxide. Soil Sci., 152(2): 72-81.

HUANG,W.W. and JING,Z. 1990. Effect of particle-size on transition-metal concentrations in the Changjiang (Yangtze-river) and the Huanghe (yellow-river), China. Sci Total Environ, 94(3): 187-207.

KABATA, A. and PENDITAS, H. 1984. Trace elements of soils and plants. Boca Raton, Florida: CRC Press.

MEIMA, J. A., VAN ZOMEREN, A. and COMANS, R. N. J. 1999. Complexation of Cu with dissolved organic carbon in municipal solid waste incinerator bottom ash leachates. Environ. Sci. Tech., 33(9): 1424-1429.

MONTES, S., RIVERA-MANCIA, S., DIAZ-RUIZ, A., et al. 2014. Copper and copper proteins in Parkinson`s Disease. Oxid. Med. Cell. Longevity, 2014: 147251.

PAL, A., KUMAR, A. and PRASAD, R. 2014. Predictive association of copper metabolism proteins with Alzheimer's disease and Parkinson's disease: A preliminary perspective. Biometals, 27(1): 25-31.

POHANKA, M. 2013. Alzheimer's disease and oxidative stress. A review. Curr. Med. Chem., 21(3): 356-364.

POHANKA, M. 2014. Copper, aluminum, iron and calcium inhibit human acetylcholinesterase in vitro. Environ Toxicol Pharmacol 37: 455-459.

POSPÍŠILOVÁ, L., VLČEK, V., HYBLER, V., et al. 2016. Standard analytical methods and evaluation criteria of soil physical, agrochemical, biological, and hygienic parameters. In: Folia Univ. Agric. Silvic. Mendelianae Brun., Vol. IX, No. 3.

SELBIG, W. R., BANNERMAN, R. and CORSI, S. R. 2013. From streets to streams: Assessing the toxicity potential of urban sediment by particle size. Science of the total environment, 444: 381-391. 